\title{
Kinetics of $\mathrm{Hg}$ and $\mathrm{Pb}$ Removal in Aqueous Solution Using Coal Fly Ash Adsorbent
}

\author{
Eko Prasetyo Kuncoro ${ }^{1}$ and Mochammad Zakki Fahmi ${ }^{2}$
}

\begin{abstract}
Water pollution caused by heavy metals is a serious problem to environment. $\mathrm{Hg}$ and $\mathrm{Pb}$ are heavy metals having high toxicity level. Heavy metals treatment is necessary before releasing them to environment. The use of adsorption method is interesting because of its relatively simple operation. The development of adsorption is oriented to the use of industrial waste such as coal fly ash. The objective of this research is to investigate the kinetics aspect of $\mathrm{Hg}$ and $\mathrm{Pb}$ adsorption using coal fly ash. A series of a $\mathrm{Hg}$ and $\mathrm{Pb}$ adsorption experiment using coal fly ash with time variation was carried out. The results were plotted to pseudo first order kinetic and pseudo second order kinetic model. The conclusion obtained was that $\mathrm{Hg}$ and $\mathrm{Pb}$ adsorption kinetics followed pseudo second order kinetic model.
\end{abstract}

Keywords- Hg, Pb, Coal Fly Ash, Adsorption, Kinetics.

Abstrak-Pencemaran air yang disebabkan oleh logam berat merupakan masalah yang serius terhadap lingkungan. Hg dan Pb merupakan logam berat dengan tingkat toksisitas yang tinggi. Pengolahan logam berat sebelum dibuang ke lingkungan adalah hal yang perlu dilakukan. Penggunaan metode adsorpsi merupakan metode yang menarik karena relatif mudah. Perkembangan adsorpsi banyak diarahkan pada pemanfaatan limbah industri seperti abu layang batu bara. Tujuan dari penelitian ini adalah untuk mengetahui aspek kinetik dari adsorpsi $\mathrm{Hg}$ dan Pb menggunakan abu layang batu bara. Serangkaian seri percobaan adsorpsi $\mathrm{Hg}$ dan Pb dengan abu layang batu bara terhadap variasi waktu telah dilakukan. Hasil percobaan diplot menurut pseudo first order kinetic dan pseudo second order kinetic model. Dari hasil yang didapat dapat disimpulkan bahwa kinetika adsorpsi Hg dan Pb dengan abu layang batu bara mengikuti pseudo second order kinetic model.

Keywords—Hg, Pb, Abu Layang Batu Bara, Adsorpsi, Kinetik.

\section{INTRODUCTION}

M any production activities had ameliorated the condition of human life. These activities produced products, services, and wastes. Heavy metals wastes are the wastes that treat human life. They are toxic and tend to accumulate in the organism tissues. Many researches focused on $\mathrm{Hg}$ and $\mathrm{Pb} . \mathrm{Hg}$ and $\mathrm{Pb}$ are found as waste in the industrial activities. The effect of $\mathrm{Hg}$ exposure to the environment can be found in Minamata tragedy documentation where $\mathrm{Hg}$ was considered as pollutants that caused birth defect and neural problem. The recent researches showed that $\mathrm{Hg}$ had correlation with cardiovascular disease [1]. The effects of $\mathrm{Pb}$ exposure to environment are neurogical disorders, birth defects, and growth retardation [2].

Because of its danger, $\mathrm{Hg}$ and $\mathrm{Pb}$ waste are needed to be treated before release to the environment. There are many methods adapted to reduce heavy metals toxicity [3.4.5]. Chemical precipitation is the most used technique to remove heavy metals, heavy metals precipitated in hydroxide form. This technique is useful to handle high concentration of heavy metals but it provides sludge problem to the environment. Membrane filtration is an emerging technique used to remove heavy metals. Laboratory researches showed that this technique could remove low concentration of heavy metals but it has disadvantage for its high cost of membrane. Adsorption becomes the most used technique beside precipitation to remove heavy metals. It is relatively easy to operate and high separation can be obtained for low concentration of heavy metals.

${ }^{1}$ Eko Prasetyo Kuncoro is with Departement of Biology, Universitas Airlangga, Surabaya, Indonesia. E-mail: ekopkuncoro@yahoo.com

${ }^{2}$ Mochammad Zakki Fahmi is with Departement of Chemistry, Universitas Airlangga, Surabaya, Indonesia.
The recent progress of adsorption is the use of waste materials as adsorbents. There are wastes from agricultural and industrial wastes. These types of wastes are found in high quantity as solid wastes. Further treatments to handle these wastes are needed. Combustion and landfill are usually practiced but these methods have limitations so the use of wastes as adsorbents is considered as a good choice. One of the industrial wastes is coal fly ash. It can be found from thermal power plant using coal as fuel for combustion. The capability of coal fly ash to remove various heavy metals had been reported [6]. Kinetic aspect of adsorption is important for the design of adsorption system. It provides important information of adsorbate rate removal.

The objective of this study was to evaluate kinetic aspect of $\mathrm{Hg}$ and $\mathrm{Pb}$ adsorption onto coal fly ash.

\section{METHOD}

\section{A. Preparation of Adsorbent}

Coal fly ash used in this research was obtained from a thermal power plant in Paiton, East Java province. Preparation of adsorbent was followed procedures in the previous work [7]. Several treatments were given to the coal fly ash before using to kinetic experiments. Coal fly ash was heated at $120^{\circ} \mathrm{C}$ for 24 hours in the oven then it was sieved to get the particle size of $149-250 \mu \mathrm{m}$. Fifteen gram of coal fly ash obtained then was mixed with 100 $\mathrm{mL}$ of $0.1 \mathrm{M} \mathrm{CH}_{3} \mathrm{COOH}$, then the solution was stirred for one hour and it was stabilized for 16 hours. The solution then filtered by Buchner filter. The sample of coal fly ash obtained was heated at $120^{\circ} \mathrm{C}$ for 24 hours in the oven before it was ready to use. 


\section{B. Preparation of metals solution}

The metals solutions were prepared by dissolving metals salts $\left(\mathrm{Hg}\left(\mathrm{NO}_{3}\right)_{2}\right.$ and $\left.\mathrm{Pb}\left(\mathrm{NO}_{3}\right)_{2}\right)$ in to demineralized water. The concentration of $\mathrm{Hg}$ and $\mathrm{Ni}$ solutions used for kinetic experiments was $100 \mathrm{mg} / \mathrm{L}$.

\section{Batch kinetics study}

To study adsorption kinetic aspect of $\mathrm{Hg}$ and $\mathrm{Pb}$ onto coal fly ash, a set of kinetic experiments was carried out. Six bottles of $\mathrm{Hg}$ solution $(100 \mathrm{mg} / \mathrm{L})$ were mixed with $15 \mathrm{~g}$ of coal fly ash and the solutions were shaken for appropriate times. The solutions were filtered and analyzed by AAS (Shimidzu, Japan) to determine the residual concentration of $\mathrm{Hg}$. The same procedure was used for $\mathrm{Pb}$ solution. The results of kinetic experiments were plotted to pseudo first order, pseudo second order, and intra-particle diffusion kinetic model.

\section{Pseudo first order kinetic model}

The pseudo first order kinetic model is given by the following equation [8]:

$\ln \left(q_{e}-q_{t}\right)=\ln q_{e}-k_{1} t$

where $\mathrm{q}_{\mathrm{e}}$ is the amount of heavy metal adsorbed at equilibrium, $\mathrm{q}_{\mathrm{t}}$ is the amount of heavy metal adsorbed at time $\mathrm{t}, \mathrm{k}_{1}$ is the pseudo first order rate constant.

\section{E. Pseudo second order kinetic model}

The pseudo second order kinetic model is given by the following equation [9]:

$\frac{t}{q_{t}}=\frac{1}{k_{2} q_{e}^{2}}+\frac{1}{q_{e}}$

where $\mathrm{k}_{2}$ is the pseudo second order rate constant.

\section{$F$. Intra-particle diffusion kinetic model}

The intra particle diffusion kinetic model is given by the following equation [10]:

$q_{t}=k_{i d}(t)^{1 / 2}$

where $\mathrm{k}_{\mathrm{id}}$ is the intra-particle diffusion coefficient.

\section{RESULT AND DISCUSSION}

Figure 1 and 2 present the results of $\mathrm{Hg}$ and $\mathrm{Pb}$ adsorption kinetic experiments. $\mathrm{X}$ axis represents time while $Y$ axis represents comparison of metal concentration at time $\mathrm{t}$ and initial metal concentration. The equilibrium condition was obtained after 350 minutes of contact time for both $\mathrm{Hg}$ and $\mathrm{Pb}$ adsorption by coal fly ash. In the beginning of adsorption until 200 minutes of contact time, the $\mathrm{Hg}$ removal was $80 \%$ while the $\mathrm{Pb}$ removal was $60 \%$. The metal uptake by adsorbent depends on the metals type. The use of coal fly ash was interesting for $\mathrm{Hg}$ removal until 200 minutes because it provided relatively faster $\mathrm{Hg}$ removal than the use for $\mathrm{Pb}$ removal. After 300 minutes of contact time, the value of $\mathrm{Hg}$ and $\mathrm{Pb}$ removal was around $80 \%$. In general the adsorption of metals is increase as a function of time.

The characteristics of metals removal by coal fly ash depend on the origin and nature of coal fly ash. Alinnor [11] reported that equilibrium of $\mathrm{Pb}$ and $\mathrm{Cu}$ removal by coal fly ash from Nigeria was obtained after 60 minutes of contact time while Al-Zboon [12] reported also that 60 minutes of contact time was needed for equilibrium of $\mathrm{Pb}$ removal using coal fly ash from a Jordanian cement plant. Visa et al. [13] reported that a short contact time of 10 minutes was needed for the equilibrium of $\mathrm{Pb}$ removal by coal fly ash activated by $\mathrm{NaOH}$. Coal fly ash used was obtained from a Romanian thermal power plant. Munoz and Aller [14] reported that equilibrium of $\mathrm{Pb}$ by coal fly ash from Spanish thermal power plant obtained after 20 minutes of contact time.

To determine the best-fitting kinetic model, linear regression was used. The best kinetic model could be used as reference to know rate-controlling step in the metals adsorption. The plot of $\ln \left(\left(q_{e}-q_{t}\right) / q_{e}\right)$ versus $\mathrm{t}$, $t / q_{t}$ versus $\mathrm{t}, \mathrm{q}_{\mathrm{t}}$ versus $\mathrm{t}^{1 / 2}$ was used to investigate pseudo first order, pseudo second order, and intraparticle diffusion kinetic model respectively. Figure 3, 4, and 5 present pseudo first order, pseudo second order, and intra-particle diffusion kinetic model plot respectively for $\mathrm{Hg}$ adsorption by coal fly ash. The value of linear regression coefficient $\left(\mathrm{R}^{2}\right)$ was 0.9629 for pseudo first order kinetic model plot. The higher value of linear regression coefficient obtained from pseudo second order and intra-particle diffusion kinetic model plot: 0.9906 and 0.9891 respectively. This result suggested that $\mathrm{Hg}$ adsorption by coal fly ash followed pseudo second order kinetic model. In this model, the mechanism involved was chemical reaction mechanism [15]. In this case, there was a chemical bond that was formed at adsorbent surface. Pseudo second order kinetic model was also successfully applied to the kinetic adsorption of $\mathrm{Hg}$ by adulsa leaf powder, bamboo leaf powder and sulfurized adsorbent from agricultural waste $[16,17,18]$. Table 1 presents the comparison of the linear regression coefficient of $\mathrm{Hg}$ adsorption kinetic model using various adsorbents.

Figure 6, 7, and 8 present the plot of kinetic model investigated for $\mathrm{Pb}$ adsorption by coal fly ash.

Linear regression coefficient of pseudo first order kinetic model was 0.9555 while linear regression coefficient of pseudo second order and intra-particle diffusion kinetic model was 0.871 and 0.9739 respectively. This result was different from the result obtained in the case of $\mathrm{Hg}$ adsorption. The highest value of linear regression coefficient was obtained for intraparticle diffusion kinetic model. This result suggested that the mechanism involved was surface adsorption [19]. However the pseudo second order kinetic model could be applied for this case, the value of linear regression coefficient was relatively high. Pseudo second order kinetic model was also successfully applied to the kinetic adsorption of $\mathrm{Pb}$ by Solanum melongena and Cinnamomum camphora leaf powder [20]. Using Solanum melongena leaf powder as adsorbent, the linear regression coefficient of pseudo first order, pseudo second order, and intra-particle diffusion kinetic model was $0.958,0.999$, and 0.976 . Table 2 shows the comparison of the linear regression coefficient of $\mathrm{Pb}$ adsorption kinetic model using various adsorbents.

\section{CONCLUSION}

The kinetic aspect of $\mathrm{Hg}$ and $\mathrm{Pb}$ adsorption by coal fly ash was investigated. Pseudo first order, pseudo second order, and intra-particle diffusion kinetic model was used. Pseudo second order kinetic model could be applied to the adsorption kinetic of $\mathrm{Hg}$ and $\mathrm{Pb}$ by coal fly ash. 


\section{ACKNOWLEDGEMENT}

The authors acknowledged DIKTI-Airlangga University for financial support through Riset Unggulan.

\section{REFERENCE}

[1] Jyrki $\mathrm{K}$ Virtanen, $\mathrm{T} \mathrm{H}$ Rissanen, $\mathrm{S}$ Voutilainen, and $\mathrm{T} \mathrm{P}$ Tuomainena, "Mercury as a Risk Factor for Cardiovascular Diseases," Journal of Nutritional Biochemistry, vol. 18, no. 2, pp. 75-85, February 2007.

[2] M Ahameed and M K J Siddiqui, "Environmental Lead Toxicity and Nutritional Factors," Clinical Nutrition, vol. 26, no. 4, pp. 400-408, August 2007.

[3] T A Kurniawan, G Y S Chan, W H Lo, and S Babel, "PhysicoChemical Treatment Techniques for Wastewater Laden with Heavy Metals," Chemical Engineering Journal, vol. 118, no. 1-2, pp. 83-98, May 2006.

[4] M A Barakat, "New Trends in Removing Heavy Metals from Industrial Wastewater," Arabian Journal of Chemistry, vol. 4, no. 4, pp. 361-377, October 2011.

[5] Fengliang Fu and Qi Wang, "Removal of Heavy Metal Ions from Wastewaters: A Review," Journal of Environmental Management, vol. 92, no. 3, pp. 407-418, March 2011.

[6] M Ahmaruzzaman, "A review on the Utilization of Fly Ash," Progress in Energy and Combustion Science, vol. 36, no. 3, pp. 327-363, June 2010

[7] E P Kuncoro and $\mathrm{M} \mathrm{Z} \mathrm{Fahmi,} \mathrm{"Removal} \mathrm{of} \mathrm{Hg}$ and $\mathrm{Pb}$ in Aqueous Solution using Coal Fly Ash Adsorbent," in International Conference on Earth Science and Technology, Bandung, 2012, pp. 377-382.

[8] M Balsamo, F Di Natale, A Erto, A Lancia, and F Montagnaro, "Cadmium Adsorption by Coal Combustion Ashes-Based Sorbents-Relationship Between Sorbent Properties and Adsorption Capacity," Journal of Hazardous Materials, vol. 187, no. 1-3, pp. 371-378, March 2011.

[9] Y S Ho and G McKay, "Pseudo-Second Order Model for Sorption Processes," Process Biochemistry, vol. 34, no. 5, pp. 451-465, July 1999

[10] M Yurtsever and I A Sengil, "Biosorption of $\mathrm{Pb}(\mathrm{II})$ Ions by Modified Quebracho Tannin Resin," Journal of Hazardous Materials, vol. 163, no. 1, pp. 58-64, April 2009.

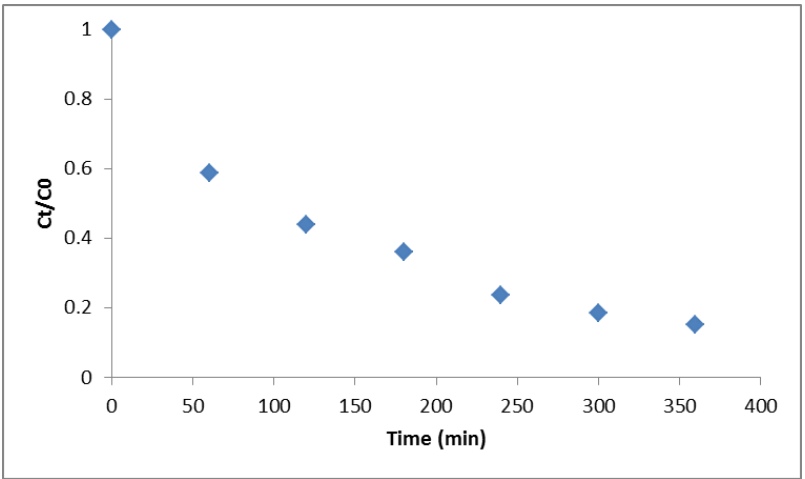

Figure 1. Kinetic of $\mathrm{Hg}$ adsorption by coal fly ash

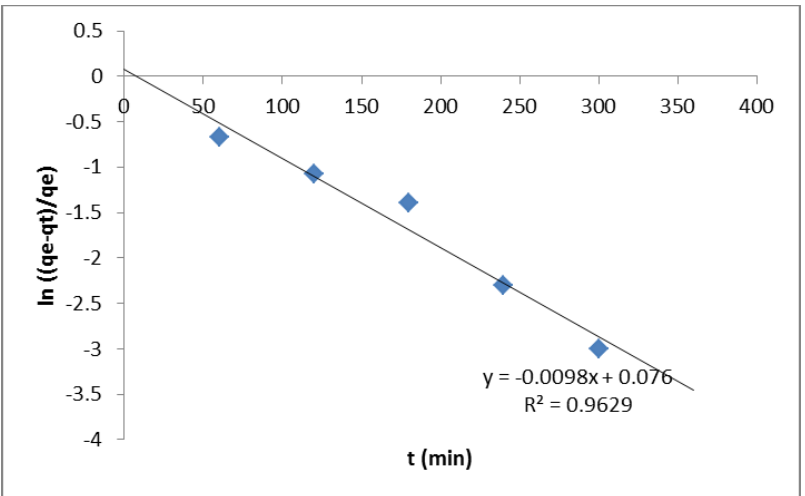

Figure 3. Pseudo first order kinetic plot of Hg adsorption by coal fly ash
[11] I J Alinnor, "Adsorption of Heavy Metal Ions from Aqueous Solution by Fly Ash," Fuel, vol. 86, no. 5-6, pp. 853-857, March 2007.

[12] K Al-Zboon, M S Al-Harahsheh, and F B Hani, "Fly ash-based geopolymer for Pb Removal from Aqueous Solution," Journal of Hazardous Materials, vol. 188, no. 1-3, pp. 414-421, April 2011.

[13] M Visa, L Isac, and A Duta, "Fly ash Adsorbents for MultiCation Wastewater Treatment," Applied Surface Science, vol 258, no. 17, pp. 6345-6352, June 2012.

[14] M I Minoz and A J Aller, "Chemical Modification of Coal Fly Ash for the Retention of low Levels of Lead from Aqueous Solutions," Fuel, vol. 102, pp. 135-144, December 2012.

[15] Y S Ho and G McKay, "Sorption of Dyes and Copper Ions onto Biosorbents," Process Biochcem, vol. 38, no. 7, pp. 1047-1061, February 2003

[16] M Aslam, S Rais, M Alam, and A Pugazhendi, "Adsorption of $\mathrm{Hg}$ (II) from Aqueous Solution using Adulsa (Justicia Adhotoda) Leaves Powder: Kinetic and Equilibrium Study," Journal of Chemistry, pp. 1-11, 2013.

[17] D K Mondal, B K Nandi, and M K Purkait, "Removal of Mercury (II) from Aqueous Solution using Bamboo Leaf Powder: Kinetic, Thermodynamic and Kinetic Studies," Journal of Environmental Chemical Engineering, vol. 1, no. 4, pp. 891-898, December 2013.

[18] N Asasian and T Kaghazchi, "A Comparison on Efficiency of Virgin and Sulfurized Agro-Based Adsorbents for Mercury Removal from Aqueous Systems," Adsorption, vol. 19, no. 1, pp. 189-200, February 2012.

[19] M M Areco and M dos Santos Afonso, "Copper, Zinc, Cadmium and Lead Biosorption by Gymnogongrus Torulosus. Thermodynamics and Kinetics Studies," Colloids and Surfaces B. Interfaces, vol. 81, no. 2, pp. 620-628, December 2010.

[20] G Yuvaraja, N Krishnaiah, M V Subbaiah, and A Krishnaiah, "Biosorption of $\mathrm{Pb}(\mathrm{II})$ from Aqueous Solution by Solanum Melongena Leaf Powder as Low-Cost Biosorbent Prepared from Agricultural Waste," Colloids and Surfaces B: Biointerfaces, vol. 114, pp. 75-8, February 2014.

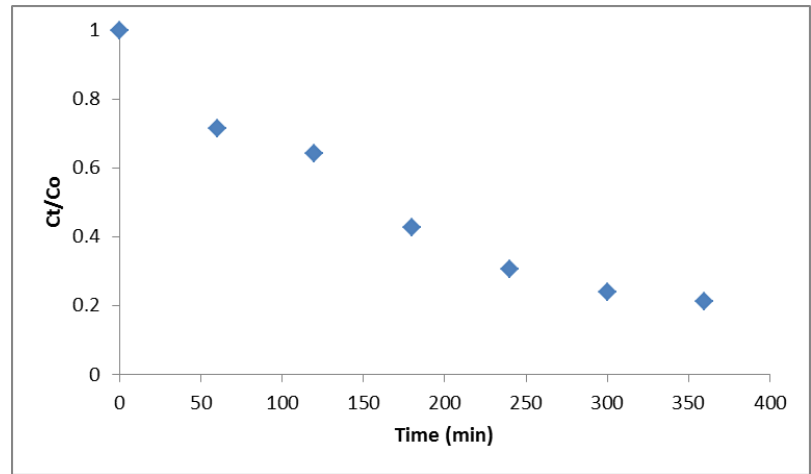

Figure 2. Kinetic of $\mathrm{Pb}$ adsorption by coal fly ash

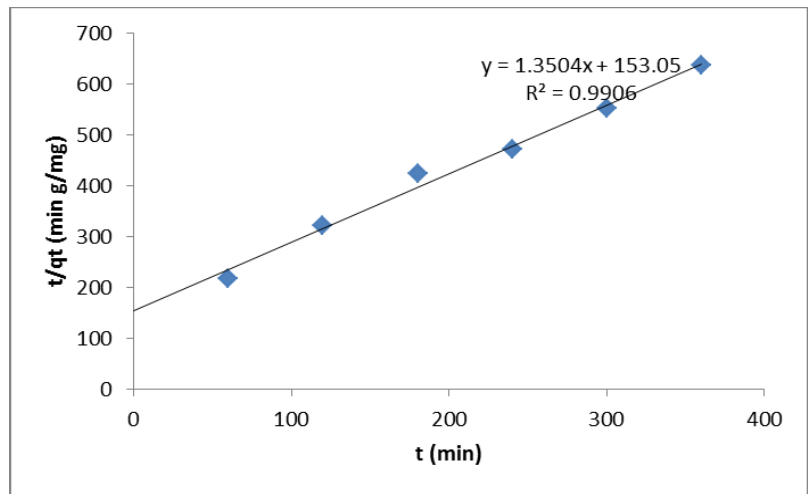

Figure 4. Pseudo second order kinetic plot of Hg adsorption by coal fly ash 


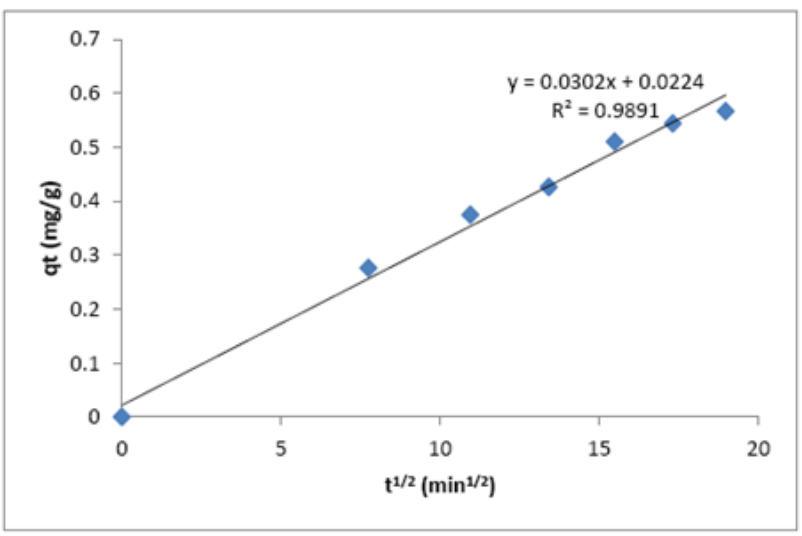

Figure 5. Intra-particle diffusion kinetic plot of $\mathrm{Hg}$ adsorption by coal fly ash

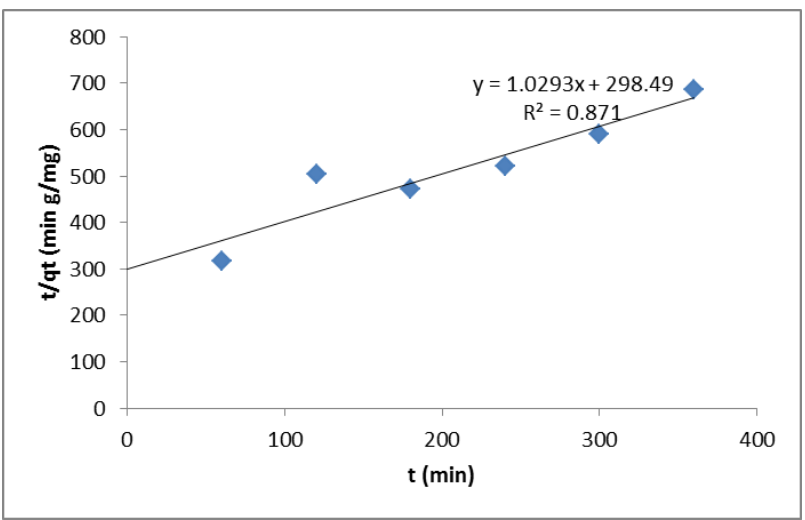

Figure 7. Pseudo second order kinetic plot of $\mathrm{Pb}$ adsorption by coal fly ash

TABLE 1.

COMPARISON OF THE LINEAR REGRESSION COEFFICIENT OF HG ADSORPTION KINETIC MODEL

\begin{tabular}{cccccc}
\hline \hline Adsorbate & Adsorbent & $\begin{array}{c}\mathrm{R}^{2} \text { (pseudo } \\
\text { first order) }\end{array}$ & $\begin{array}{c}\mathrm{R}^{2} \text { (pseudo } \\
\text { second } \\
\text { order) }\end{array}$ & $\begin{array}{c}\mathrm{R}^{2} \text { (intra- } \\
\text { particle } \\
\text { diffusion) }\end{array}$ & Reference \\
\hline $\mathrm{Hg}$ & $\begin{array}{c}\text { Adulsa leaf } \\
\text { powder }\end{array}$ & 0.9830 & 0.9980 & 0.9152 & {$[16]$} \\
$\mathrm{Hg}$ & $\begin{array}{c}\text { Bamboo leaf } \\
\text { powder }\end{array}$ & 0.9700 & 0.9900 & - & {$[17]$} \\
$\mathrm{Hg}$ & $\begin{array}{c}\text { Coal fly ash } \\
\text { treated by } \\
\text { CH } \text { H }_{3} \text { COOH }\end{array}$ & 0.9629 & 0.9906 & 0.9810 & This study \\
& $\begin{array}{c}\text { Sulfurized } \\
\text { adsorbent from } \\
\text { agricultural waste }\end{array}$ & 0.8460 & 1.0000 & - & {$[18]$} \\
\hline \hline
\end{tabular}

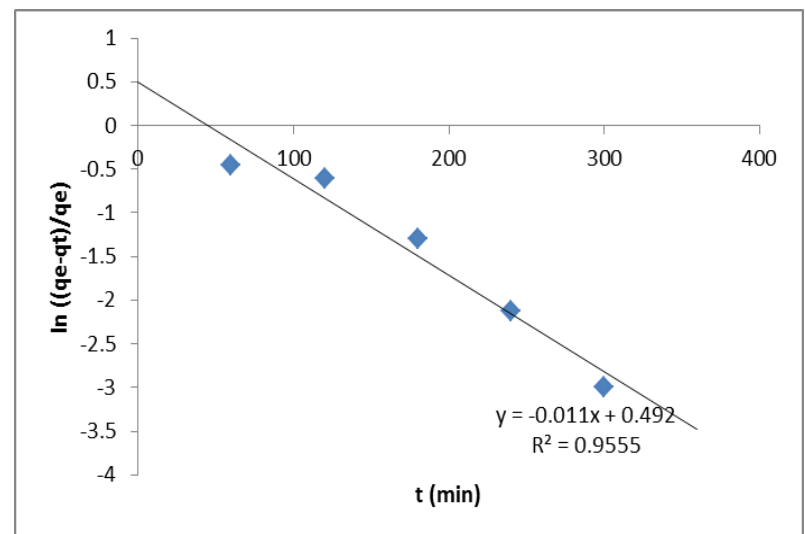

Figure 6. Pseudo first order kinetic plot of $\mathrm{Pb}$ adsorption by coal fly ash

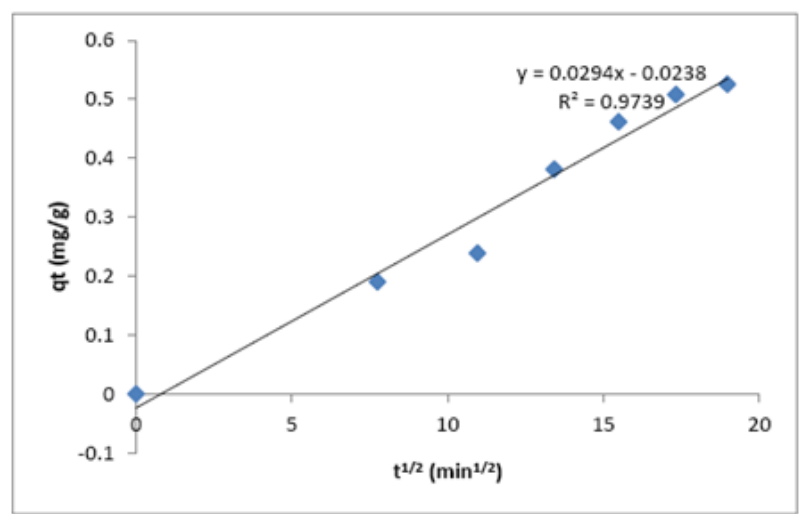

Figure 8. Intra-particle diffusion kinetic plot of $\mathrm{Pb}$ adsorption by coal fly ash

TABLE 2.

COMPARISON OF THE LINEAR REGRESSION COEFFICIENT OF PB ADSORPTION KINETIC MODEL

\begin{tabular}{cccccc}
\hline \hline Adsorbate & Adsorbent & $\begin{array}{c}\mathrm{R}^{2} \text { (pseudo } \\
\text { first order) }\end{array}$ & $\begin{array}{c}\mathrm{R}^{2} \text { (pseudo } \\
\text { second } \\
\text { order) }\end{array}$ & $\begin{array}{c}\mathrm{R}^{2} \text { (intra- } \\
\text { particle } \\
\text { diffusion) }\end{array}$ & Reference \\
\hline $\mathrm{Pb}$ & $\begin{array}{c}\text { Coal fly ash } \\
\text { treated by NaOH } \\
\text { Coal fly ash } \\
\text { treated by } \\
\mathrm{CH}_{3} \mathrm{COOH} \\
\mathrm{Pb}\end{array}$ & 0.83300 & 1.00000 & 0.40700 & {$[13]$} \\
& $\begin{array}{c}\text { Solanum } \\
\mathrm{Pb}\end{array}$ & 0.95550 & 0.87100 & 0.97390 & This study \\
& $\begin{array}{c}\text { melongena leaf } \\
\text { powder }\end{array}$ & 0.95800 & 0.99900 & 0.97600 & {$[20]$} \\
$\mathrm{Pb}$ & $\begin{array}{c}\text { Cinnamomum } \\
\text { camphora } \text { leaf } \\
\text { powder }\end{array}$ & 0.92027 & 0.99996 & 0.59452 & {$[21]$} \\
\hline \hline
\end{tabular}

